\title{
Hinweise Fur Autoren - Instructions To Authors
}

Ethische und rechlliche Voraussetzu Igen: Zur Publikation eingereichte Manuskripte müssen bei Untersuchungen an Probanden oder Patienten die Erklärung enthalten, daß das

Versuchsprotokoll von einer Ethik-kommission genehmigt wurde und somit den ethischen

Standards der Deklaration von Helsinki 1964 entspricht. Gleichzeitig ist die Einwilli-gung der Versuchsperson nach Aufklärung im Text des Manuskriptes zu fixieren. Hinweise, die auf die Identität der Versuchsperson schließen lassen, sind zu vermeiden.

Tierversuchsvorhaben bedürfen gleichfalls der Genehmigung und müssen den Forderungen des Tierschutzgesetzes in seiner Fassung von 1986 entsprechen. Auf diese Genehmigung ist im Manuskript hinzuweisen. Arbeiten, die nicht aus der Bundesrepublik Deutschland stammen, müssen einen vergleichbaren Hinweis tragen.

1. Allgemeines, Verlagsrecht

Bitte senden Sie İhr Manuskript direkt an den Verlag S. Karger, z. Hd. Frau M. Zeller, Lörracher Str. 16 a, D-79115 Freiburg. Beiträge erscheinen als Übersichtsarbeiten, Originalarbeiten, laufen-de klinische Studien, FAX-Kommunikation, Kasuistiken, klinisch-pathologische Konferenz, Briefe an die Herausgeber, Kongreßbe-richte, Informationen für die Klinik, Wilsede Schule, Buchbespre-chungen, Industrieforum und Mitteilungen onkologischer Gesell-schaften. Übersichtsarbeiten, Originalarbeiten, laufende klinische Studien. FAX-Kommunikation und Kasuistiken sind in englischer Sprache ab-zufassen. Alle anderen Beiträge können wahlweise in deutscher oder englischer Sprache eingereicht werden.

Das Manuskript soil in satzreifem Zustand in dreifacher Ausfertigung eingereicht werden. Die Entscheidung über die Annahme wissen-schaftlicher Beiträge erfolgt aufgrund mehrerer Gutachten. Eine Ko-pie des Manuskripts soil grundsätzlich beim Autor verbleiben.

Typographische Gestaltung und redaktionelle Bearbeitung sind dem Verlag vorbehalten. Die Arbeit darf nicht gleichzeitig zur anderweitigen Veröffentlichung eingereicht sein. Es ist Sache des Autors, die Nachdruckerlaubnis für Abbildungen, Tabellen usw. aus anderen Publikationen zu be-schaffen. Mit der Annahme des Manuskriptes zur Publikation gehen alle Rechte auf den Verlag über. Ohne schriftliche Genehmigung des Verlages dürfen diese Publikationen oder Teile daraus nicht in andere Sprachen übersetzt oder in irgendeiner Form mit mechanischen oder elektronischen Mitteln (einschließlich Fotokopie, Tonaufnahme und Mikrokopie) reproduziert oder auf einem Datenträger oder einem Computersystem gespeichert werden.

Geschützte Markennamen müssen mit einem hochgestellten ${ }^{\circledR}$ be-zeichnet werden. Die Verantwortung für die korrekte Befolgung die-ser Vorschrift liegt ausschließlich beim Autor.

2. Manuskripte

Diese sollen 10 Textseiten nicht überschreiten, in 1/2-zeiligem Ab-stand geschrieben sein, links und rechts einen angemessen breiten Rand aufweisen und (einschließlich Titelseite und Literaturverzeich-nis) kontinuierlich durchnumeriert sein. Folgende Gliederung wird empfohlen: Titelseite mit Titel und Kurztitel der Arbeit in Deutsch und Englisch; Autorenangabe; Institutsangabe in der Landessprache der Autoren. 
Zusammenfassung und Schlüsselwörter in Englisch und Deutsch. Zu-sammenfassungen sind zu strukturieren in: Hintergrund, Material und Methoden, Ergebnisse, Schlußfolgerungen. In die Zusammenfassung gehören keine Literaturzitate, Tabellen, Abbildungen und Ab-bildungs- und Tabellenhinweise sowie allgemein gehaltene Aussagen. Zu einer Arbeit gehören 3-5

Schlüsselwörter.

Textseiten der Arbeit mit Gliederung in Einleitung, Material und Methoden (oder: Patientengut und Methoden), Ergebnisse, Diskussion.

Fußnoten (gegebenenfalls numeriert) am unteren Rand jederTextseite. Abkürzungen bitte möglichst sparsam verwenden. Bei speziellen

Abkürzungen jeweils beim ersten Auftreten das Wort ausschreiben und die später verwendete Abkürzung in Klammern folgen lassen: z.B. Adenosin-Monophosphat (AMP).

Danksagungen sollten unmittelbar dem Text folgen und dem Litera-turverzeichnis vorangestellt sein.

Das Literaturverzeichnis soil nur die im Text zitierten Publikationen enthalten. Die Literatur ist entsprechend der Reihenfolge im Text zu numerieren. Sämtliche Autoren einer Arbeit sollen notiert werden; der Ausdruck «et al.» ist zu vermeiden. Es sollen nur Arbeiten, die entweder publiziert oder zur Publikation angenommen sind, zitiert werden. Der Passus «in Vorbereitung» oder «persönliche Mitteilung» ist zu vermeiden.

Literaturzitate werden mit oder ohne Angabe des Erstautors in den Text eingefügt, z. B. [1] oder Romberg [1] oder Romberg et al. [1].

Zur Abfassung von Literaturzitaten gelten folgende Beispiele:

Darstellungsschema einer Zeitschriftenreferenz: Kauffman HF, van der Heide S, Beaumont F, Blok H, de Vries K: Class-specific antibody determination against Aspergillus fumigatus by means of the enzyme-linked immunosorbent assay. III. Comparative study: IgG, IgA, IgM ELISA titers, precipitating antibodies and IgE binding after fractionation of the antigen. Int Arch Allergy Appl Immunol 1986;80:300-306.

Darstellungsschema einer Buchreferenz:

Hardy WD Jr. Essex M: FeLV-induced feline acquired immune deficiency syndrome: A model for human AIDS; in Klein E (ed): Acquired Immunodeficiency Syndrome. Prog Allergy. Basel, Karger, 1986, vol 37, pp 353-376.

Die Zahl von Abbildungen und Tabellen soil niedrig gehalten werden und darauf abzielen, den Text zu erläutern. Abbildungen werden mit (Abb. 1), Tabellen mit (Tab. 1) in den Text eingefügt. Be-reits im Text genannte Zahlen bedürfen keiner Wiederholung in einer Tabelle. Umgekehrt brauchen die in Tabellen zusammengestell-ten Zahlen nicht im Text wiederholt zu werden. Farbabbildungen können angenommen werden, bedürfen aber eines Reproduktions-und Druckkostenzuschusses, den der Autor zu tragen hat. Abbildungsvorlagen sind 3 fach als Papierabzüge einzureichen. Vor-lagen nicht aufkleben, lochen oder mit Büroklammern anheften; auf der Rückseite den Namen des Autors, den Titel des Beitrags, die Angabe, wo «oben» ist, sowie die Bildnummer angeben. Alle Abbildungen und Tabellen sind mit einer Legende zu versehen. Alle Legenden einer Arbeit werden auf einer gesonderten Seite zu-sammengestellt. Die Legenden sind kurz und präzise zu halten und sollen die Abbildungen bzw. Tabellen vollständig erklären. Die Interpretation der Daten erfolgt nicht in der Legende, sondern ausschließlich im Text.

Übersichtsarbeiten folgen nicht der Gliederung von Originalarbeiten. Titelseite, Zusammenfassung, Schlüsselwörter und Literaturverzeichnis sind jedoch wie oben beschrieben erforderlich. 


\section{Autorenadresse}

Postanschrift des Autors am Schluß der Arbeit vollständig angeben.

3. Kosten und Sonderdrucke

Übersteigen die Kosten der Autorkorrektur 10\% der Satzkosten, müssen diese dem Autor in Rechnung gestellt werden. Dem Autor stehen 25 Gratissonderdrucke seiner Arbeit zu.

(C) 1994 S. Karger GmbH. Freiburg

Ethical and legal prerequisites: Manuscripts handed in for publication dealing with examinations of probands and patients must include the declaration that the trial protocol has been approved by an ethical committee and thus meets the standards of the Declaration of Helsinki (1964). At the same time the proband's informed consent has to be included in the manuscript. Information suitable to reveal the proband's identity is to be avoided.

Planned animal experiments demand consent as well and must meet the requirements of the German laws protecting animals in the version of 1986. A reference to this approval must be included in the manuscript. Articles from outside the FRG have to include a comparable notice.

1. General Remarks - Publishing Laws

Please send your manuscript directly to S. KARGER Publishers, attn.: Mrs. M. Zeller, Lörracher Str. 16 a, D-79115 Freiburg. Contributions are classified as review articles, original papers, ongoing clinical trials, FAX communication, casuistic contributions, clinical pathological conference, letters to the editors, congress reports, clinical information, Wilsede School, book reviews, industrial forum, and reports of Oncological Societies.

Review articles, original papers, ongoing clinical trials, FAX communication and casuistic contributions must be written in English. All other contributions may be handed in optionally in German or English.

The manuscript should be submitted in triplicate, ready for printing. Acceptance of scientific contributions is based on the evaluation by several referees. The author should always keep a copy of the manuscript. The publisher reserves the right to edit the manuscript and decide on the layout.

The manuscript is received with the understanding that it is not under simultaneous consideration for publication elsewhere. It is the author's responsibility to obtain permission to reproduce illustrations, tables etc. from other publishers. Once the manuscript is accepted for publication, all the rights will be retained by the publisher. The publication, or parts of it, may not be translated into other languages, or reproduced by any mechanical or electronic means (including photocopying, recording and microcopying), or stored in a retrieval system without the publisher's written permission. Registered trade names must be marked with the superscript registration symbol ${ }^{\circledR}$. It is the sole responsibility of the author to ensure that this rule is followed properly.

\section{Manuscripts}

The text of the manuscripts should be limited to 10 pages and should be typed in a spacing of 1 $1 / 2$ lines with adequately wide margins (left and right). They should be consecutively numbered (including front page and reference list). We recommend the following division:

Front page with title and short title in German and English: authors' names, institute name in the native language of the authors.

Summary and Key Words in English and German (translation by the editor is possible).

Summaries should be structured in: Background, Material and Methods, Results, Conclusions.

Summaries should not include any references, tables, figures, references to figures and tables and general statements. Each article should have 3-5 key words. 
Text pages should be divided into Introduction, Materials and Methods (optionally Patients and Methods), Results, Discussion.

Footnotes (with numbers) are placed at the bottom of each page of the text.

Please use abbreviations as economically as possible. Special abbreviations should be written in full when first mentioned followed by the abbreviation in parentheses, e.g. adenosine monophosphate (AMP).

Acknowledgements should be placed directly after the text and before the list of references.

The list of references should include only the publications cited in the text. The references should be numbered according to their order of appearance in the text. In each reference all authors should be denoted, 'et al.' should not be used. It is recommended to quote only articles which have been either published already or accepted for publication. Please avoid passages like 'in preparation' or 'personal communication'.

Quotes from references are inserted into the text with or without the name of the first author, e.g. [1], or Romberg [1] or Romberg et al.

For references the following examples are compulsory:

Outline of a magazine reference:

Kauffman HF, van der Heide S, Beaumont F, Blok H, de Vries K: Class-specific antibody determination against Aspergillus fumigatus by means of the enzyme-linked immunosorbent assay . III. Comparative study: IgG, IgA, IgM ELISA titers, precipitating antibodies and IgE binding after fractionation of the antigen. Int Arch Allergy Appl Immunol 1986;80:300-306. Outline of a book reference:

Hardy WD Jr, Essex M: FeLV-induced feline acquired immune deficiency syndrome: A model for human AIDS; in Klein E (ed): Acquired Immunodeficiency Syndrome. Prog Allergy. Basel, Karger, 1986, vol 37, pp 353-376.

The number of figures and tables should be limited and aim to illustrate the text. Figures are listed in the text as (fig. 1), tables as (table 1). Figures already mentioned in the text need not be repeated in a table. Accordingly, numbers used in tables need not be repeated in the text. Figures in color may be accepted, provided the author is prepared to defray the costs involved. Original figures should be submitted in triplicate. Do not fasten them with glue or paper clips or punch holes in them. Please state on the back the author's name, the title of the article, the 'top' instruction and the number of the figure.

All figures and tables must include a legend. All legends should be listed together on a separate page. Legends should be kept short and precise and should illustrate the figures and tables exhaustively. The data should not be interpreted in the legend but exclusively in the text. Review articles do not adhere to the framework of original papers. The title page, a summary, key words and a list of references (see above) are, however, compulsory.

Author's address

Please give the author's full address at the bottom of the article.

3. Costs of Reprints

The author will be charged for corrections to the galley proofs entailing expenses in excess of $10 \%$ of the original typesetting costs. The author is entitled to 25 free reprints of his or her article.

652

Hinweise für Autoren · Instructions to Authors 